\title{
The Challenges of Anti-Corruption Initiatives: Reflections on Strategies of the Defunct Kenya's Anti-Corruption Commission
}

\author{
Dr. Wycliffe Amukowa \\ Senior Lecturer, School of Education \\ Mount Kenya University, Kenya \\ Email:kwamukowa@yahoo.com
}

Doi:10.5901/mjss.2013.v4n2p481

\begin{abstract}
This paper is founded on the growing need to eradicate corruption in the society. The causes and effects of corruption, and how to combat it, are issues that are on the increase on national, regional and international agenda. The United Nations Convention against Corruption, the African Union Convention on Preventing and Combating Corruption, the United Nations Convention against Transnational Organized Crime, the United Nations Declaration against Corruption and Bribery in International Commercial Transactions, and the International Code of Conduct for Public Officials are living testimonies. These calls to eradicate corruption present puzzles that scholarly investigations need to take lead role and centre stage in unravelling them. This scenario appeals for both theoretical and practical discourse, which is the root foundation of this paper.
\end{abstract}

Key Words: Corruption, Anti-corruption, initiatives, Legislation

\section{Introduction}

Unprecedented efforts have been made to raise awareness about corruption, its insidious nature and the damaging effects it has on the welfare of entire nations and their peoples. As Bardhan (1997) noted, corruption not only distorts economic decision-making, it also deters investment, undermines competitiveness and, ultimately, weakens economic growth. Indeed, according to Johnston (1997), there is evidence that the social, legal, political and economic aspects of development are all linked, and that corruption in any one sector impedes development in them all. As observed by Heidenheimer and Michael (2002), there is now increasing recognition throughout the public and private sector that corruption is a serious obstacle to effective government, economic growth and stability. Consequently, in the mind of Njui (n.d) anti-corruption policies and legislations are urgently required at the national and international level.

This paper presents a critical analysis and an appraisal of anti-corruption initiatives through a reflection of the strategies used by the defunct Kenya Anti-corruption Commission. The paper shows the ineffectiveness of anti-corruption initiatives by underscoring the changing character of corruption and the failures of various initiatives towards its eradication.

\section{Corruption: A definition}

The term "corruption" is used as a shorthand reference for a large range of illicit or illegal activities. Although there is no universal or comprehensive definition as to what constitutes corrupt behaviour, the most prominent definitions share a common emphasis upon the abuse of public power or position for personal advantage. The Oxford Unabridged Dictionary (2002) defines corruption as perversion or destruction of integrity in the discharge of public duties by bribery or favour while Merriam Webster's Collegiate Dictionary (2006) defines corruption as inducement to wrong by improper or unlawful means (as bribery).

The succinct definition utilized by the World Bank (1997) is: "the abuse of public office for private gain." This definition is similar to that employed by Transparency International (TI 2006), the leading NGO in the global anticorruption effort, it (TI) maintains that corruption involves behaviour on the part of officials in the public sector, whether politicians or 
civil servants, in which they improperly and unlawfully enrich themselves, or those close to them, by the misuse of the public power entrusted to them.

Muthomi (2006) argued that the conception of corruption varies among scholars. The narrowest understanding of corruption sees the vice as the abuse of public office for private gain. Muthomi noted that broadly defined, corruption is the abuse of not only public office but also private or commercial office for private gain. It invariably involves giving something to someone in a position of power either in government or in a corporation, so that he will (ab)use his power and act in a manner favouring the giver. It involves the offering, giving, soliciting or acceptance of an inducement or reward, which may influence the action of any person. (Muthomi, 2006:2)

According to Ruhiu (n.d), definition of corruption depends on one's own experience. However, whichever way one looks at it, it is a moral disease that permeates all the levels of the society. According to Procter (1980), corruption is a behaviour that is not honest or legal by people in official positions. Van Tulden, Frank, and Abraham van der Torre (1997) observed that there is no single, comprehensive, universally accepted definition of corruption. Attempts to develop such a definition invariably encounter legal, criminological and, in many countries, political problems. Indeed, this observation is well illustrated by the efforts of the UN to define corruption. According to Monica (2004) when the negotiations of the United Nations Convention against Corruption began in early 2002, one option under consideration was not to define corruption at all but to list specific types or acts of corruption. Monica observed that proposals to require countries to criminalize corruption mainly covered specific offences or groups of offences that depended on what type of conduct was involved, whether those implicated were public officials, whether cross-border conduct or foreign officials were involved, and if the cases related to unlawful or improper enrichment (Monica, 2004:66).

According to Kenya Anti-Corruption and Economic Crimes Act, 2003 corruption means an offence that involves bribery, fraud, embezzlement or misappropriation of public funds, abuse of office, breach of trust; or an offence involving dishonesty- in connection with any tax, rate or impost levied under any Act; or under any written law relating to the elections of persons to public office; (The Anti-Corruption and Economic Crimes Act, 2003:4f).

What emerges from the attempts to define corruption as reviewed above is that there seems to be no knowledge of what really corruption is. In fact as it emerges from the the Anti-Corruption and Economic Crimes Act, 2003, in Kenya, corruption is synonymous with bribery, embezzlement or any such action as contained in the Act. This implies that anticorruption initiatives are being directed towards something unknown. This paper henceforth notes that lack of conceptual clarity, could perhaps be one cause for the supposed failed attempts to fight corruption.

\section{Forms of Corruption}

Murphy, Shleifer and Vishny (1991) argued that corruption is well understood through its forms. They noted that many specific forms of corruption are clearly defined and understood, and are the subject of numerous legal or academic definitions. Miller (2001) agreed with Murphy, Shleifer and Vishny (1991) and added that many of the forms of corruption are criminal offences, although in some cases Governments consider that specific forms of corruption are better dealt with by regulatory or civil law controls.

Muthomi (2006) argued that Corruption manifests itself in one or more of various forms, viz. bribery, extortion, fraud, embezzlement and other forms of malfeasance by public or corporate officials. He maintained that though universal in its existence, the pervasiveness of corruption varies across nations and organizations. Corruption occurs in different forms, in different types of organizations and at different levels. Typologies of corruption include Grand Corruption, Political Corruption, Corporate Corruption, Administrative Corruption and Petty Corruption. Petty corruption is the common man's version of corruption. It is said that petty corruption involves small sums paid to low-level officials to "grease the wheels" or cut through bureaucratic red tape (Muthomi, 2006: 4). This section discusses in detail, some of the forms of corruption mentioned in this paragraph as follows.

\section{Grand and Petty Corruption}

According to TI (207), Grand corruption is corruption that pervades the highest levels of a national Government, leading to a broad erosion of confidence in good governance, the rule of law and economic stability. Petty corruption can involve the exchange of very small amounts of money, the granting of minor favours by those seeking preferential treatment or the employment of friends and relatives in minor positions (TI). The most critical difference between grand corruption and petty corruption is that the former involves the distortion or corruption of the central functions of Government, while the latter develops and exists within the context of established governance and social frameworks. 


\section{Active and Passive Corruption}

Rose-Ackerman (1999) argued that in discussions of transactional offences such as bribery, "active bribery" usually refers to the offering or paying of the bribe, while "passive bribery" refers to the receiving of the bribe. In criminal law terminology, the terms may be used to distinguish between a particular corrupt action and an attempted or incomplete offence. For example, "active" corruption would include all cases where payment and/or acceptance of a bribe had taken place. According to UN (2004), it does not include cases where a bribe was offered but not accepted, or solicited but not paid. In the formulation of comprehensive national anti-corruption strategies that combine criminal justice with other elements, such distinctions are less critical. Nevertheless, care should be taken to avoid confusion between the two concepts.

\section{Bribery}

Simis (1982) argued that bribery is the bestowing of a benefit in order to unduly influence an action or decision. It can be initiated by a person who seeks or solicits bribes or by a person who offers and then pays bribes. Anechiarico and Jacobs (1998) noted that bribery is probably the most common form of corruption known. Definitions or descriptions appear in several international instruments, in the domestic laws of most countries and in academic publications. The "benefit" in bribery can be virtually any inducement: money and valuables, company shares, inside information, sexual or other favours, entertainment, employment or, indeed, the mere promise of incentives. The benefit may be passed directly or indirectly to the person bribed, or to a third party, such as a friend, relative, associate, favourite charity, private business, political party or election campaign (Anechiarico \&Jacobs, 1998:78).

According to Ades \& Di Tella (1997), the conduct for which the bribe is paid can be active: the exertion of administrative or political influence or it can be passive: the overlooking of some offence or obligation. Bribes can be paid individually on a case-by-case basis or as part of a continuing relationship in which officials receive regular benefits in exchange for regular favours. Ades \& Di Tella maintained that in jurisdictions where criminal bribery necessarily involves a public official, the offence is often defined broadly to extend to private individuals offered bribes to influence their conduct in a public function, such as exercising electoral functions or carrying out jury duty (Ades \& Di Tella, 1997: 38). Baker (2005) holds that public sector bribery can target any individual who has the power to make a decision or take an action affecting others and is willing to resort to bribery to influence the outcome. Politicians, regulators, law enforcement officials, judges, prosecutors and inspectors are all potential targets for public sector bribery.

Provisions that define or criminalize bribery include: article 8 of the UN Convention Against Transnational Organized Crime, GA/Res/55/25, Annex and article VI of the Inter-American Convention against Corruption of 29 March 1996 (OAS Convention), which require Parties to criminalize offering of or acceptance by a public official of an undue advantage in exchange for any act or omission in the performance of the official's public functions. Article 1 of the OECD Convention on Combating Bribery of Foreign Public Officials in International Business Transactions and Article VIII of the OAS Convention require Parties to criminalize the offering of bribes by nationals of one State to a Government official of another in conjunction with a business transaction.

Articles 2 and 3 of the European Union Convention on the Fight Against Corruption Involving Officials of the European Communities or officials of Member States of the European Union, Journal C 195, 25/06/1997, pp.2- 11 (1997), requires Parties to criminalize the request or receipt by a public official of any advantage or benefit in exchange for the official's action or omission in the exercise of his functions ("passive bribery"), as well as the promise or giving of any such advantage or benefit to a public official ("active bribery"). The Council of Europe's Criminal Law Convention on Corruption, ETS No. 173 (1998), goes further by criminalizing "active" and "passive" bribery of, inter alia, domestic public officials, foreign public officials, domestic and foreign public assemblies, as well as private sector bribery, trading in influence and account offences.

\section{Embezzlement, Theft and Fraud}

As noted by Ferrero and Brosio (1997), in the context of corruption, embezzlement, theft and fraud all involve the taking or conversion of money, property or valuable items by an individual who is not entitled to them but, by virtue of his or her position or employment, has access to them. Hindess (2001), held that a number of recent international legal instruments have sought to ensure that Parties have offences addressing this type of conduct with varying degrees of specificity. These include the Organization of American States' Inter-American Convention against Corruption (1996) and the 
European Union's Convention drawn up on the basis of Article K.3 of the Treaty on European Union, on the protection of the European Communities' financial interests (1995). Klitgaard, Ronald and Parris (2000) noted that as with bribery and other forms of corruption, many domestic and international legal definitions are intended to form the basis of criminal offences. Thus, they include only those situations involving a public official or where the public interest is crucially affected.

According to the UN Anti-corruption Toolkit (2004), in some legal definitions "theft" is limited to the taking of tangible items, such as property or cash, but non-legal definitions tend to include the taking of anything of value, including intangibles such as valuable information. In the Toolkit, the broader meaning of "theft" is intended. Examples of corrupt theft, fraud and embezzlement abound. Virtually anyone responsible for storing or handling cash, valuables or other tangible property is in a position to steal it or to assist others in stealing it, particularly if auditing or monitoring safeguards are inadequate or non-existent. Employees or officials with access to company or Government operating accounts can make unauthorized withdrawals or pass to others the information required to do so.

Brunetti and Weder (1998) held that elements of fraud are more complex. Officials may create artificial expenses; "ghost workers" may be added to payrolls or false bills submitted for goods, services, or travel expenses. The purchase or improvement of private real estate may be billed against public funds. Employment-related equipment, such as motor vehicles, may be used for private purposes. In one case, World Bank-funded vehicles were used for taking the children of officials to school, consuming about 25 per cent of their total use (World Bank, 1997).

\section{Extortion}

Ades and Di Tella (1997) observed that whereas bribery involves the use of payments or other positive incentives, extortion relies on coercion, such as the use or threat of violence or the exposure of damaging information, to induce cooperation. They (Ades and Di Tella, 1997) argue that as with other forms of corruption, the "victim" can be the public interest or individuals adversely affected by a corrupt act or decision. In extortion cases, however, a further "victim" is created, namely the person who is coerced into cooperation. While extortion can be committed by Government officials or insiders, such officials can also be victims of it.

According to African Union (2003), the Union's Convention requires Parties to criminalize the use or presentation of false or incorrect representations or non-disclosure of information the effect of which is the misappropriation or wrongful retention of funds from the budget of the European Communities. The UN (2006) points out that officials in a position to initiate or conduct criminal prosecution or punishment often use the threat of prosecution or punishment as a basis for extortion. Alternatively, officials who have committed acts of corruption or other wrongdoings may be threatened with exposure unless they themselves pay up. Low-level extortion, such as the payment of "speed money" to ensure timely consideration and decision-making of minor matters by officials, is widespread in many countries.

\section{Abuse of Discretion}

According to Klitgaard, Ronald and Parris (2000) in some cases, corruption can involve the abuse of discretion, vested in an individual, for personal gain. For example, an official responsible for Government contracting may exercise the discretion to purchase goods or services from a company in which he or she holds a personal interest or propose real estate developments that will increase the value of personal property. Such abuse is often associated with bureaucracies where there is broad individual discretion and few oversight or accountability structures, or where decision making rules are so complex that they neutralize the effectiveness of any accountability structures that do exist.

\section{Favouritism, Nepotism and Clientelism}

Monica (2004) observed that generally, favouritism, nepotism and clientelism involve abuses of discretion. Such abuses, however, are governed not by the self-interest of an official but the interests of someone linked to him or her through membership of a family, political party, tribe, religious or other group. If an individual bribes an official to hire him or her, the official acts in self-interest. If a corrupt official hires a relative, he or she acts in exchange for the less tangible benefit of advancing the interests of family or the specific relative involved (nepotism). As Hopkins (2002) reported, the favouring of, or discriminating against, individuals can be based on a wide range of group characteristics: race, religion, geographical factors, political or other affiliation, as well as personal or organizational relationships, such as friendship or membership of clubs or associations. 


\section{Conduct Creating or Exploiting Conflicting Interests}

As noted in the United Nations Manual on Anti-corruption Policy (2004), most forms of corruption involve the creation or exploitation of some conflict between the professional responsibilities of a corrupt individual and his or her private interests. The acceptance of a bribe creates such a conflict of interest. Most cases of embezzlement, theft or fraud involve an individual yielding to temptation and taking undue advantage of a conflict of interest that already exists. In both the public and private sector, employees and officials are routinely confronted with circumstances in which their personal interests conflict with their responsibility that require them s to act in the best interests of the State or their employer.

\section{Improper Political Contributions}

According to Kimberly (1997), one of the most difficult challenges in developing anti-corruption measures is to make the distinction between legitimate contributions to political organizations and payments made in an attempt to unduly influence present or future activities by a party or its members once they are in power. A donation made because the donor supports the party and wishes to increase its chances of being elected is not corrupt; it may be an important part of the political system and, in some countries, is a basic right of expression or political activity protected by the constitution. A donation made with the intention or expectation that the party will, once in office, favour the interests of the donor over the interests of the public is tantamount to the payment of a bribe.

Tanzi, and Ludger (1997) argued that regulating political contributions has proved difficult in practice. Donations may take the form of direct cash payments, low-interest loans, the giving of goods or services or intangible contributions that favour the interests of the political party involved. Tanzi, and Ludger further noted that one common approach to combating the problem is to introduce measures that seek to ensure transparency by requiring disclosure of contributions, thus ensuring that both the donor and recipient are politically accountable. Another is to limit the size of contributions to prevent any one donor from having too much influence (Tanzi \& Ludger, 1997:34).

As it is apparent from this section, corruption is a multifaceted behaviour, that is to say, it has many forms. This pseudopodal character as has been reviewed has made anti-corruption agencies to try and fight corruption from its forms. Accordingly therefore, the assumption seems to be that for example, when one stops bribery or extortion, then is stopping corruption. In mathematical theorization, this seems to rest on an assumption that the sum total of parts of a thing is equal to the thing. To what extend this assumption could be entertained rests a philosophical reflections.

\section{Causes of Corruption}

Without proper vigilance and effective countermeasures, corruption can occur anywhere. Recent corruption cases exposed in the World Bank (1997) and the United Nations (2004) have shown that any society or organization is susceptible, even where well established checks and balances are in place. Combating corruption, building integrity and establishing credibility require time, determination and consistency. When anti-corruption strategies are first instituted, a long-term process begins, during which corrupt values and practices are gradually identified and eliminated. In most cases, a complex process of interrelated elements is involved: reforms to individual institutions take place in stages as problems are identified; countermeasures are developed and implemented; personnel are reoriented and retrained.

Corruption is generally connected with the activities of the state and especially with the monopoly and discretionary power of the state. Therefore, as Gary Becker, Nobel Laureate in economics, pointed out in one of his Business Week columns if we abolish the state, we abolish corruption. But, of course, quite apart from the fact that corruption can exist in the private sector, a civilized society cannot function without a state, and in modern, advanced societies, the state must have many functions (Becker \& Stigler, 1974:74). The Becker argument seems to collide with the reality that some of the least corrupt countries in the world, such as Canada, Denmark, Finland, the Netherlands, and Sweden, have some of the largest public sectors, measured as shares of tax revenue or public spending in gross domestic product. Thus, the solution to the problem of corruption may not be as simple as just reducing the level of taxation or public spending. According to Miller (2001), the existence of these regulations and authorizations gives a kind of monopoly power to the officials who must authorize or inspect the activities. These officials may refuse the authorizations or may simply sit on a decision for months or even years. Thus, they can use their public power to extract bribes from those who need the authorizations or permits. 


\section{Taxation}

According to Tanzi (1998), corruption is likely to be a major problem in tax and customs administrations when the laws are difficult to understand and can be interpreted differently so that taxpayers need assistance in complying with them; the payment of taxes requires frequent contacts between taxpayers and tax administrators; the wages of the tax administrators are low; acts of corruption on the part of the tax administrators are ignored, not easily discovered, or when discovered penalized only mildly; the administrative procedures (e.g. the criteria for the selection of taxpayers for audits) lack transparency and are not closely monitored within the tax or customs administrations; tax administrators have discretion over important decisions, such as those related to the provision of tax incentives, determination of tax liabilities, selection of audits, litigations, and so on; and more broadly, the controls from the state (the principal) on the agents charged with carrying out its functions are weak (Tanzi, 1998:64ff).

According to Kpundeh (2006) in some countries, at one time, corruption became so endemic in the tax administration (e.g., Peru and Uganda) that the government decided to close down the existing administrations and to replace them by new ones. In several countries, customs administrations have been very corrupt, leading to the jailing of the director of customs and in several cases resulting in the replacement of the domestic customs organizations with the services of foreign companies.

\section{Provision for Goods and Services at Below-Market Prices}

Rauch and Peter (1997) observed that in most countries, the government engages in the provision of goods, services, and resources at below-market prices for example, foreign exchange, credit, electricity, water, public housing, some rationed goods, access to educational and health facilities, access to public land, and so on. Even access to some forms of pensions, such as those for disability, fall into this category because the individuals who get them have paid less in contributions to the pension funds over time than the pension they get once their disability status is approved. In some countries, disability pensions have been a fertile ground for corruption. In others, some individuals benefited enormously when they were able to get access to large amounts of credit or foreign exchange at below-market prices. Rauch and Evans argued that sometimes, because of limited supply, rationing or queuing becomes unavoidable. Excess demand is created and decisions have to be made to apportion the limited supply. These decisions are often made by public employees. Those who want these goods (the users) would be willing to pay a bribe to get access (or a higher access) to what the government is providing. It is thus not surprising that in all the areas mentioned above, cases of corruption have been reported (Rauch and Peter, 1997: 32).

Decisions such as those described above are often worth a lot to individuals or enterprises. Theobald (1990) argued that it is natural that attempts will be made by some of them to get favourable decisions, in some cases by paying bribes and in other cases by simply exploiting close personal relations with public officials. He held that the bribes may be paid to public officials whose salaries may be very low and whose "temptation price" may be far less than the value of the potential benefit from a favourable decision to the bribers (Theobald, 1990:24).

\section{Levels of the Bureaucracy}

The quality of the bureaucracy varies greatly among countries. In some, public sector jobs give a lot of prestige and status; in others, much less so. Many factors contribute to that quality. Many years ago Max Weber (1947), the outstanding German sociologist, described what should be the characteristics of an ideal bureaucracy. Tradition and the effect that it has on the pride that individuals have in working for the government may explain why, all things being equal, some bureaucracies are much more efficient and much less vulnerable to corruption than others. Rauch and Peter (1997) have gathered information on the degree to which civil servants' recruitment and promotions are merit based for 35 developing countries. Their results indicate that the less recruitment and promotion are based on merit, the higher is the extent of corruption. Rauch and Evans concluded that absence of politically motivated hiring, patronage, and nepotism, and clear rules on promotions and hiring, in addition to some of the factors discussed separately below, all contribute to the quality of a bureaucracy (Rauch \& Peter, 1997:56).

\section{Level of Public Sector Wages}

Over the years many observers have speculated that the wages paid to civil servants are important in determining the 
degree of corruption. For example, Assar Lindbeck (1998) attributes the low corruption in Sweden in this century partly to the fact that at the turn of the century, high-level administrators earned 12-15 times the salary of an average industrial worker. Assar Lindbeck says that one can speculate that there may be corruption due to greed and corruption due to need. The higher the wage level, the lower is corruption (Assar Lindbeck, 1998:67). The relationship between wage level and corruption index has been tested empirically by Van Rijckeghem and Weder (1997). In other words, the fight against corruption, pursued exclusively on the basis of wage increases, can be very costly to the budget of a country and can achieve only part of the objective. Furthermore, as argued above, even at high wages some individuals may continue to engage in corrupt practices.

Impact of Corruption

Many scholars have identified several effects of corruption. Kibwana (2001) observed that corruption tends to concentrate wealth, not only increasing the gap between rich and poor but providing the wealthy with illicit means to protect their positions and interests. Kibwana held that, in turn, can contribute to social conditions that foster other forms of crime, social and political instability and even terrorism. Corruption can be found in all walks of life. It hinders economic development, diverts investments in infrastructure, institutions and social services and also undermines efforts to achieve other country specific targets (Kibwana, 2001: 63).

Braguinsky (1996) argued that whereas corruption may often occur in private, its implications for society in general are grave and this must form the basis for the unyielding response against it. Braguinsky maintains that Irrespective of the perpetrators of corruption, there are costs borne by society, which is the basis for the refusal to tolerate it. Principally, corruption harms society and the economy by diverting resources towards less deserving people. In this manner the more deserving within the economy are short-changed. For instance due to corruption, resources may be allocated without considerations of priority and where the returns may be optimised (Braguinsky, 1996: 34f).

As Mbula (2008) notes examples of the effects of corruption where resources are not optimally used are numerous in Kenya and do involve claims of favouritism of some people or even regions at the expense of others. In this regard Mbula cautioned that If this occurs again and again, the people or institutions that are capable of contributing to growth are stifled (Mbula, 2008: 5). Crank and Caldero (2004) ccorruption is harmful to a society and the economy since its effect is equivalent to taxing honest work and instead rewarding mediocrity and dishonesty. As such, genuine hardworking people are demotivated since merit ceases to be the basis of reward. Crank and Caldero observed that the competitive edge in institutions and people, which is essential to good service, is replaced by competition in corrupt practices and this distorts the nature of any market, and in turn the policies that govern such markets. A common argument heard in business circles is that survival is impossible without competition (Crank and Caldero, 2004: 123).

According to Kaufmann and Siegelbaum (1996), where corruption is perverse, injustice is perpetrated because those with an unethical orientation get privileged access to resources and services to which others are excluded. It is in this regard that Kaufmann and Siegelbaum held that this aggravates social injustice and increases poverty while this social and economic exclusion translates into class disharmony. Exclusion maintaining the tensions increases to the extent that the whole society is under structural strain. Societies in which exclusion is reinforced by corruption do experience instability that may result in violence and massive destruction. Finally, at the purely commercial level, corruption does discourage investments because it raises substantially the transaction costs in the conduct of business. Due to the additional cost, the goods and services procured through the corruption process are uncompetitive (Kaufmann and Siegelbaum, 1996:65).

Klitgaard (1991) observed that corruption has severe implications for the economy because it causes a gradual depression in the investments as the costs contingent to corruption cut down on the expected returns. Businesses then withdraw to places or countries where there is an atmosphere more conducive to investment. Klitgaard emphasized that the prime consequence to the economy is that corruption does cause the loss of investment, both local and foreign. Since no rational investor will knowingly establish a business in a corrupt country, the need to deal decisively with this problem is imperative (...) (Klitgaard, 1991:47).

\section{Actions against Corruption}

As KACC (2008) notes, efforts towards capacity building to combat corruption are still believed to be in their infancy in most countries, and reliable information about the nature and extent of domestic and transnational corruption is difficult to obtain. The problems of corruption are compounded by the very broad nature of the phenomenon and lack of consensus 
about legal or criminological definitions that could form the basis of international and comparative research. According to the United Nations (2001), corruption can be found in all walks of life. It hinders economic development, diverts investments in infrastructure, institutions and social services and also undermines efforts to achieve other country specific targets. As a result, the UN notes that the international community has become increasingly concerned with the problem of corruption and its negative impact on economic growth and poverty alleviation (UN, 2001:112).

As World Bank (1997) points out development partners, international organizations, non-governmental organizations and academic experts on corruption have advocated for an integrated and comprehensive approach to fighting corruption around the globe. This includes: introducing new or amended legislation aimed at reducing public officials' opportunities for rent-seeking; building alliances with other governments in the struggle against corruption by signing international anti-corruption agreements; and the implementation of anti-corruption programmes.

Action against corruption is high on the global agenda and anti-corruption efforts by the international community have led to the establishment of global and regional initiatives to fight corruption. Among them are the UN Convention against Corruption; the African Union Convention on Preventing and Combating Corruption; the UN Convention against Transnational Organized Crime; the UN Declaration against Corruption and Bribery in International Commercial Transactions; and the International Code of Conduct for Public Officials.

The United Nations Convention against Corruption, finalised on 30 September 2003 and adopted by the General Assembly in its resolution 58/4 of 31 October 2003, represents a major step forward in the global fight against corruption, and in particular in the efforts of UN Member States to develop a common approach to both domestic efforts and international cooperation. Through the Convention the UN urges all States and competent regional economic integration organizations to sign and ratify the United Nations Convention against Corruptions soon as possible in order to ensure its rapid entry into force (UN, 2004:1f).

The UN Convention can be seen as the most recent of a long series of developments in which experts have recognised the far-reaching impact of corruption and the need to develop effective measures against it at both the domestic and international levels. It is now widely accepted that measures to address corruption go beyond criminal justice systems and are essential to establishing and maintaining the most fundamental good governance structures, including domestic and regional security, the rule of law and social and economic structures which are effective and responsive in dealing with problems, and which use available resources as efficiently and with as little waste as possible.

The gradual understanding of both the scope and seriousness of the problem of corruption can be seen in the evolution of international action against it, which has progressed from general consideration and declarative statements, to the formulation of practical advice, and then to the development of binding legal obligations and the emergence of numerous cases in which countries have sought the assistance of one another in the investigation and prosecution of corruption cases and the pursuit of proceeds. The States Parties to this Convention agreed to promote and strengthen measures to prevent and combat corruption more efficiently and effectively; to promote, facilitate and support international cooperation and technical assistance in the prevention of and fight against corruption, including asset recovery and to promote integrity, accountability and proper management of public affairs and public property (UN, 2003: $5 \mathrm{ff})$.

The Convention in its Preventive measurescontains a compendium of preventive measures which goes far beyond those of previous instruments in both scope and detail, reflecting the importance of prevention and the wide range of specific measures which have been identified by experts in recent years. Specific requirements include the establishment of specialized procedures and bodies to develop domestic prevention measures; private-sector prevention measures; measures directed at general prevention in the public sector as well as at specific critical areas such as public procurement and financial management and the judiciary; and measures to prevent money-laundering.

The Convention calls on States Parties to establish or maintain a series of specific criminal offences including not only long-established crimes such as various forms of bribery and embezzlement, but also conduct which may not already be criminalised in many States, such as trading in official influence and other abuses of official functions. This has proven a powerful anticorruption instrument in the hands of many States, but would be impossible for others to implement because of constitutional or legal requirements, particularly those regarding the presumption of innocence.

Other measures found in the Convention include offences relating to obstruction of justice (Art.25) and money laundering (Art.23), the establishment of jurisdiction to prosecute (Art.42), the seizing, freezing and confiscation of proceeds or other property (Art.31), protection of witnesses, experts and victims and others (Art.32-33), other matters relating to investigations and prosecutions (Art.36- 41), and the requirement that some form of civil, criminal or administrative liability must be established for legal persons (Art.26). The Convention emphasizes international cooperation as basic in the fight against corruption and calls for the extradition of offenders, mutual legal assistance and 
less-formal forms of cooperation in the course of investigations and other law-enforcement activities. Consequently, offenders may be extradited without dual criminality where this is permitted by the law of the requested State Party. The underlying rule, applicable to all forms of cooperation, is that where dual-criminality is required, it must be based on the fact that the relevant States Parties have criminalised the conduct underlying an offence, and not whether the actual offence provisions coincide.

Through AUCPCC, the member states agreed to promote and strengthen the development in Africa by each State Party, of mechanisms required to prevent, detect, punish and eradicate corruption and related offences in the public and private sectors. Promote, facilitate and regulate cooperation among the State Parties to ensure the effectiveness of measures and actions to prevent, detect, punish and eradicate corruption and related offences in Africa. Coordinate and harmonize the policies and legislation between State Parties for the purposes of prevention, detection, punishment and eradication of corruption on the continent. Promote socio-economic development by removing obstacles to the enjoyment of economic, social and cultural rights as well as civil and political rights. Establish the necessary conditions to foster transparency and accountability in the management of public affairs (AU, 2003:1).

\section{Anti-corruption Legislation in Kenya}

\section{The Prevention of Corruption Act Cap.65 of 1956}

Anti-corruption initiatives and establishment of related institutions in Kenya can be traced back to The Prevention of Corruption Act (Cap.65 of 1956). The Act was primarily to be enforced by the Police Department. Despite its existence, corruption grew over the years. Efforts were made to establish an Anti-corruption squad within the Criminal Investigation Department of the Kenya Police, but the squad was disbanded before it could have any significant impact. The Act was amended in 1987 to provide for the establishment of the Kenya Anti-corruption Authority (KACA) to fight corruption, taking this function away from the police. Its formation was a tacit admission of the problem of corruption in Kenya at that time. According to Kibwana and Akivaga (2001), KACA investigated and proceeded to prosecute a number of public officials alleged to have engaged in corrupt practices as defined by the Act.

Part 2 of the Prevention of Corruption Act (Cap.65 of 1956) and subsequent amendments established the Kenya Anti-Corruption and Economic Crimes Board to work with the Kenya Anti-Corruption Authority (KACA). The principal functions of the board were to advise KACA on the exercise of its powers under the Act, and to approve the acceptance of grants and donations to KACA. The Economic Crimes Court was also established under the Prevention of Corruption Act Cap.65 of 1956 and subsequent amendments. It exercised unlimited jurisdiction in respect of crimes under the Act itself. The Act vested power in KACA's officers to conduct investigations, obtain information necessary for presentation before the court, effect arrest for offences under the Act, and intercept private information upon an ex parte application to the court. However, in December 2000 (High Court of Kenya 2003), the High Court in the case of Gachiengo vs. Republic (2000) ruled that the existence of KACA undermined the powers conferred on both the Attorney General and the Commissioner of Police by the Constitution of the Republic of Kenya. Consequently, KACA was disbanded.

\section{The Anti-corruption and Economic Crimes Act 2003}

The object of the Anti-Corruption and Economic Crimes Act 2003 was to provide for the prevention, investigation and punishment of corruption, economic crimes and related offences and incidental matters. The Act embodied a broad conception of corruption viz. bribery, fraud, embezzlement or misappropriation of public funds, abuse of office, and breach of trust or an offence involving dishonesty in connection with any tax, rate or impost levied under any Act (Republic of Kenya 2003, Section 45).

Part II of the Anti-Corruption and Economic Crimes Act 2003 provided for the appointment of special magistrates with exclusive jurisdiction to try offences specified in the Act. They were obliged, as far as was practicable, to hold the trial of an offence under the Act on a day-to-day basis until completion. Part III A of the Act established the Kenya AntiCorruption Commission (KACC) as the premier institution for fighting corruption in the country, vested with a wide mandate to investigate corrupt conduct, trace and recover corruptly acquired public property, devise corruption prevention mechanisms and educate the public on the dangers of corruption. Part III B established the Kenya Anti-corruption' Commission Advisory Board as a corporate body independent and answerable only to Parliament. The Board was to advise the Kenya Anti-Corruption commission generally on the exercise of its powers and the performance of its functions under the Act. Further, it was to recommend to parliament persons to be appointed and/or removed from office as 
Director and Assistant Directors of the Commission, and to approve grants and donations to the Commission.However, on August 24th 2011, Parliament passed the Ethics and Anti-Corruption Commission Act 2011, effectively repealing the Anti-corruption and Economic Crimes Act 2003, thereby disbanding the Kenya Anti-corruption Commission.

\section{The Ethics and Anti-Corruption Commission Act 2011}

Pursuant to Article 79 of the Constitution of Kenya 2010, the Ethics and Anti-Corruption Commission (EACC) was established by the Ethics and Anti-Corruption Commission Act No.22 of 2011 (Republic of Kenya 2011). The Act mandates the Commission to, inter alia, develop and promote standards and best practices in integrity and anticorruption; oversee the enforcement of codes of ethics prescribed for public officers; monitor the enforcement of codes of conducts of members of professional bodies established under any law; advise, on its own initiative, any person on any matter within its functions; raise public awareness on ethical issues, educate the public on the dangers of corruption, and enlist and foster public support in combating corruption ; work with other State and public offices in the development and promotion of standards and best practices in integrity and anti-corruption measures, and receive complaints on the breach of the code of ethics by a public officer. The Act further provides that the Commission shall investigate and recommend to the Director of Public Prosecutions the prosecution of any acts of corruption or violation of codes of ethics or other matters prescribed under this Act or any other law enacted pursuant to Chapter Six of the Constitution.

\section{The Defunct Kenya Anti-corruption' Commission}

In 2003, the Kenya Government published the Anti-corruption and Economic Crimes Act, 2003, which led to the establishment of Kenya Anti-corruption Commission, the main government statutory agency mandated to fight corruption in Kenya. Under section 5, the Act establishes the Commission. The Act provided that (1) The Kenya Anti-Corruption Commission is hereby established as a body corporate. (2) The Commission shall have all the powers necessary or expedient for the performance of its functions. (3) Without limiting the generality of subsection (2), the Commission shall have perpetual succession and a common seal and shall be capable of-(a) suing and being sued in its corporate name; and (b) holding and alienating moveable and immovable property (Kenya Anti-Corruption and Economic Crimes Act, 2003:9f). The Commission begun to implement its functions through a three-pronged approach of Enforcement, Prevention and Public Education as an articulation of its mandate spelt out in the Anti-Corruption and Economic Crimes Act, 2003. The Constitutional establishment of KACC as a legal body to deal with incidences of corruption is an official admission that corruption is a serious problem in Kenya.

Despite the initiatives that were undertaken by KACC, several reports show that there was no reduction in incidences of corruption in Kenya. According to Transparency International (2006), Kenya remained in the bottom $10 \%$ of Transparency International's Corruption Perception Index (CPI), an indicator that Kenya was one of the world's most corrupt countries. Indeed, Kenya was ranked $144^{\text {th }}$ out of 159 countries for corruption. It was estimated that the average urban Kenyan paid 16 bribes per month. Kanyinga (2004) notes that anti-corruption initiatives in Kenya seem to bear insignificant fruits. As Kivutha and Oketch-Owiti (2005) observed, this poor performance of public institutions has made many citizens to be very sceptical of the various initiatives aimed at addressing corruption. Indeed, in introductory message (2007), the by then Director of the defunct KACC, Aaron Ringera mentioned that perception by the public of the work of KACC was a challenge. The public seemed not satisfied by the work of the Commission and even felt that the Commission targeted people who were less powerful (report referred to this as "Small fish" and "Big fish).

\section{Corruption Trends in Kenya as of the Year 2010}

According to Ringera (2007), more often than not, information about the incidence of corruption remains a matter of speculation and conjecture. "(...) this scenario not withstanding however, it is still possible for a keen observer to authoritatively postulate about the trends of corruption in Kenya in terms of its occurrence, manifestation, frequency and intensity (...)" (Ringera, 2007:16). On the basis of this observation, it would not be idle to assert that corruption is very much alive in Kenyan Society today.

As Muthomi (2006) puts it, the bottom line therefore is that while acts of corruption are no longer brazenly executed with impunity as in the past, the perpetrators of this vice are becoming more adept and sophisticated in their schemes. Ringera (2007) notes that more often than not, as recent experiences show, the corrupt are now investing time and resources to cover their tracks upfront before carrying out their activities. The cover up may take the form of socializing 
law enforcement agencies in the corrupt ventures or establishing an elaborate and intricate network of defence in the event that the cover is blown and demands for punitive action against the perpetrator become the norm of the day.

Ringera's observations over the efforts to cover up corruption compares to the arguments advanced by Bellow (2003), who argued that the strategy is what has in recent times been characterized as the ability of corruption to fight back where attempts to slay the dragon do give rise to even more dangerous beasts. Bellow (ibid), observed that this near impenetrable web of defence can take a social, political or legal form or a combination of all the three. The social strategy entails acts of largesse directed to an unsuspecting or gullible public by the barons and cartels of corruption. Once as often happens, a corrupt individual succeeds in portraying himself as the benefactor of society, it becomes very difficult for state agencies to unmask him as a social thief and therefore an enemy of the people (Bellow, 2003:67).

As Namwamba (2007) argues on the political front, the line of defence takes the form of an appeal to tribal or ethnic emotions by the corrupt. According to KACC (2007), one of the most coveted instruments of self-protection, which has over the years been deployed with devastating effect against the anti-corruption war in Kenya, is the tendency for the corrupt to portray themselves as victims of a tribal witch-hunt. KACC notes that the strategy by would be convicts to ethicize their own criminality has on many occasions succeeded in blackmailing those with the responsibility of enforcing the law into inaction (KACC, 2007:6).

Finally, law itself is almost invariably deployed as the last bulwark against the anti-corruption war. As Ringera (2007) notes, law in this regard is not just an instrument of social engineering but also a vehicle of maintaining the status quo. It becomes a tool for preserving the benefits and profits of corruption. In recent times lawyers have directed most of their energies towards the defence of those indicted of corruption on the basis that fundamental rights and freedoms of the individual are under threat. Rengera (2007) says that: "lest these last remarks be misconstrued as pouring scorn on the due process of law, let me make it absolutely clear that he is a firm believer in the rule of law. People should be punished only in accordance with the law. But when the law becomes an impediment to the achievement of social justice by offering sanctuary to those who unjustly enrich themselves at the expense of the public, then it ought to be changed to pave way for better laws. In addition, those whose sacred duty it is to interpret and enforce the law must be alive to the perpetual imperative of attuning legal procedures and processes towards facilitating quick detection, prosecution and punishment of corrupt conduct" (Ringera, 2007:x).

KACC conducted a survey that measured perceived corruption and compared the outcome with the findings of the 2005 and 2006 surveys. The 2007 Survey was carried out during the months of August and September 2007 involving 5,207 respondents spread across the country. The highlights of the survey findings show that more than three quarters of the respondents $(77.9 \%)$ understood corruption to mean giving and taking bribes. Other manifestations of corruption recognized include misuse of public resources, tribalism/nepotism/favouritism, extortion, fraud, illegal acquisition of public property and tax evasion. Over three quarters of the respondents (77.6\%) perceive corruption to be a major problem today while nearly all respondents $(91.8 \%$ and $83 \%)$ believe that "grand" and "petty" corruption respectively is very harmful to the economy (KACC, 2008:69).

According to the survey (KACC, 2008), on average, 44 percent of the respondents indicated that corruption level within public institutions has decreased, 34.3 percent believe it has increased, while 16 percent felt it has not changed. Respondents perceived the Police (Traffic, Regular and Administration) and the Provincial Administration to top the list of public agencies most involved in bribery. GovernmentHospitals, Local Authorities, National Registration Bureau, Lands Office, the Judiciary and Department of Immigration were also perceived as dens of corruption.

\section{KACC Strategies in the Fight against Corruption: A critical Overview}

The defunct Kenya Anti-Corruption Commission was the premier institution for fighting corruption in the country. It was established by law (The Anti-Corruption and Economic Crimes Act 2003) and vested with a wide mandate to investigate corrupt conduct, trace and recover corruptly acquired public property, devise corruption prevention mechanisms and educate the public on the dangers of corruption. The Commission adopted an all embracing and comprehensive strategy of executing this mission. The Commission used a three-pronged approach in the fight against corruption. These were: investigation, prevention, and mobilization of public support (Public Education). This approach was reflected in the mandate given to the Commission by law to investigate corrupt conduct; trace and recover corruptly acquired public property, advice on corruption prevention mechanisms and educate the public on the dangers of corruption. This mandate was carried out through three Directorates: The Directorate of Investigations and Asset Tracing; the Directorate of Legal Services and the Directorate of Preventive Services (Ringera, 2007: xi). 
The Directorate of Preventive Services was responsible for the implementation of four functions of the Commission as spelt out in Section 7 of the Anti-Corruption and Economic Crimes Act (No. 3 of 2003). The section stated that at the request of any person, to advise and assist the person on ways in which the person may eliminate corrupt practices; to examine the practices and procedures of public bodies in order to facilitate the discovery of corrupt practices and to secure the revision of methods of work or procedures that in the opinion of the Commission, may be conducive to corrupt practices; to advise heads of public bodies of changes in practices or procedures compatible with the effective discharge of the duties of such bodies that the Commission thinks necessary to reduce the likelihood of the occurrence of corrupt practices and to educate the public on the dangers of corruption and economic crime and to enlist and foster public support in combating corruption and economic crime (Muthomi, 2006:13).

Preventive activities therefore focused on reforming policies, practices, and procedures with a view to seal corruption loopholes and other inefficiencies that may lead to loss, poor service delivery and other malpractices. This approach, according to Christopher (2000) attempts to reach the majority of the population who, given an environment where ethical values and good governance practices are institutionalized, will not engage in corrupt practices. Christopher noted that this approach clearly differentiates prevention from investigation as the latter is mainly carried out after a crime has been committed or is about to be committed. The importance of corruption prevention cannot be underrated as it has been recognized internationally as the most effective strategy in fighting corruption (Christopher, 2000: 113).

As Muite (2007) argued, corruption loopholes exist in almost all management and operational systems in many organizations. Such loopholes may be found in the law, policies and procedures. For example, where the law vests certain individuals with discretionary powers, such powers may be abused if there is no system of checks and balances in exercising such discretion. According to KACC (2007) this overall strategy was largely defined by the legislative mandate given to the Commission by the Act. It was premised upon a vision of attaining a society with a zero tolerance for corruption. The Kenya Anti-Corruption Commission realizes that the attainment of this vision entails a clear, systematic, practical, sustained and a well-coordinated approach to combating corruption. The Commission also realized that no single individual or agency could eradicate corruption in Kenya. The strategy was therefore three pronged i.e. enforcement of the law against corruption, prevention of corruption and educating the public about and against corruption (KACC, 2007:2).

\section{Law Enforcement (Investigation and Asset Tracing)}

The Commission was empowered to investigate any conduct constituting corruption or economic crime. It was also empowered to assist any law enforcement agency in the investigation of corruption or economic crime. Where an investigation revealed that loss of or damage to public property had been occasioned by the corrupt conduct of a public officer, the Commission was empowered to institute civil proceedings against such official for the recovery of the said property including but not limited to public funds. This power extended to all property or funds outside Kenya.

The KACC Annual Report 2007/2009 makes it clear that one of the core mandates of the Commission was to conduct investigations into corruption and economic crimes and related matters reported to or detected by the Commission. The Commission placed more emphasis on proactive diction of corruption and economic crimes to disrupt corrupt activities. This pre-emptive approach saves the public money that would have otherwise been lost through corruption, dismantles corruption networks and saves on time and resources that would have been spent on post facto investigation and prosecution (KACC, 2008:4).In pursuing of its law enforcement through investigation and asset tracing initiatives, the Commission performed three main functions, namely, receiving reports, carrying out investigations, litigation and asset recovery. This section examines the performance of the Commission in these functions in detail as follows:

Reports

According to KACC 2007/2008 Annual Report, in the period July 2007 to June 2008 the Commission received 4,485 complaints at the Commissions headquarters and a further 359 reports at the Mombasa regional office which became operational in June 2007. In comparison, the Commission received 8,188 reports in 2006-2007 and 7,888 reports in 2005-2006 (KACC, 2006 \& 2007). However, the KACC 2007/2007 Annual Report noted that the drop in the number of reports received may be attributed to two main reasons, namely: General Elections campaigns which witnessed increased political activity in the period September to December 2007, and Post Election violence covering the months of 
January to March 2008 (KACC, 2008:4). It becomes apparent from this paragraph that the drop was not due to reduced cases of corruption, but that there was no access to reporting. Similarly, the view points to the fact that a drop in reported cases does not imply a reduction in corruption cases.

Investigations

During the period 2007/2008, the Commission completed 389 investigations, while 25 cases were referred to external agencies for investigations. These investigations according to KACC (2008) resulted in the arrest of 62 suspects. Some of the major investigations the Commission continued to undertake include: Security Contracts (Anglo Leasing Contracts) investigations. According to KACC (20008) the Commission continued to pursue international assistance through Mutual Legal Assistance and Agency to Agency cooperation in an endeavour to cover the international aspects but with varied successes and challenges. The Commission explained that these international investigations, through the assistance of foreign agencies, were covering jurisdictions including the United Kingdom, Spain, the United States, Jersey, Netherlands and Switzerland and extend to other jurisdictions as the investigation progresses (KACC, 20008:7).

The Commission launched further investigations into Pending Bills, in which the Commission continued to receive reports from the Pending Bills Closing Committee with recommendations for criminal investigations and civil recovery. The Commission opened eighty (80) files with claims estimated at Kshs.80 billion. On the Judiciary, the Commission instituted five (5) inquiries targeting procurement and financial irregularities in the Judiciary involving senior officials of the Judiciary while at the National Aids Control Council, the Commission continued focus on the management of funds by the National Aids Control Council. Three (3) investigations on financial irregularities by officials and agents of the National Aids Control Council were instituted.

KACC further reported that the Commission continued to focus attention on the usage of devolved funds and opened several inquiries on the use of Constituency Development Funds, the Local Authority Transfer Funds and the Fuel Levy. Investigations focused on the misuse of the funds by constituency development committees and parliamentarians, local authority staff and irregularities in the award and performance of road repair contracts through the use of fuel levy (KACC, 20008:7). Investigations continued in the sugar sector where the Commission managed, through intelligence gathered, to disrupt irregular payment of huge sums of money. Several other inquiries were ongoing. After incessant complaints by the public in regard to irregular issuance of work permits, residence permits and citizenship, the Commission instituted investigations at the Directorate of Immigration Services. (KACC, 20008:8).

\section{Asset Tracing Investigations}

In the year 2007-2008, 50 inquiry case files were opened. According to the KACC 2007/2008 Annual Report, some of the ongoing assets tracing investigations included investigation into allegations that a financial controller of a state corporation engaged in corruption /economic crimes and was in possession of unexplained assets. KACC mentioned that it was detected that the subject had suspect deposits amounting to over Kshs.128 million within one year. A search carried out in both the office and residence of the official recovered a total of Kshs.4, 308,000/= in cash. Valuation of his immovable assets was approximately Kshs.56 million (KACC, 20008:8). The KACC 2007/2008 Annual Report further reveals investigation into allegations that a chief accountant in a government ministry had accumulated wealth whose value is disproportionate to his known sources of income. In the report it is shown that a search carried out in the suspects residence recovered Kshs.1, 990,000/= in cash. Valuation of the unexplained assets was approximately Kshs.73.7 million (KACC, 20008:8).

Other issues covered the investigation into allegations that the Nucleus Estate of Miwani Sugar Company (1989) Limited (under receivership) which comprises of 9,394 acres of land and developments thereon with an estimated value of over Kshs.2.3 billion was irregularly disposed of through a public auction, Investigation into allegation of illegal acquisition of public land in Mombasa estimated at Kshs.5 million and investigation into allegations that the Kenya Sugar Board made irregular payments in the form of legal fees to the tune of Kshs.181 million to an advocate.

\section{Proactive Interventions by the Commission}

According (KACC,20008).the Commission undertook the following preemptive actions: Kenya Sugar Board, in which the Commission detected and proactively disrupted a transaction involving Kenya Sugar Board in which Kshs.2.2 billion was about to be irregularly approved and granted to a non-qualified applicant. Mombasa Old Port, where a tax evasion ring at 
the Mombasa Old Port in which unscrupulous traders evaded taxes running into millions of shillings was detected by the Commission. Kenya Ports Authority in which KACC Preventive services officers on routine systems examination at the MombasaPort detected and reported flawed procurement in progress for two ship-to-shore cranes by KPA at a cost of Kshs.1 billion.

\section{Litigation and Asset Recovery}

In carrying out its law enforcement mandate, the Commission performed functions towards the litigation and recovery of corruptly acquired asset. Under this function, the Commission investigated the extent of liability for the loss of, or damage to any public property and in appropriate cases to institute civil proceedings against any person for the recovery of such property or for compensation. The Commission noted that this function underscored the fundamental need to deprive the corrupt the benefit of their ill-gotten wealth, thereby removing the motivation to engage in corruption and economic crimes generally. (KACC, 20008:11).

Investigations undertaken by the Commission (KACC, 20008:11) were geared towards, among other things, the tracing, freezing, recovery and/or forfeiture of corruptly acquired wealth. These processes, as observed above, served to deprive the motivation invariably underlying every corrupt transaction and break the corruption vicious cycle. The Commission maintained that effective implementation of these recovery processes is one of the criteria by which status of compliance by states parties which are signatory to the United Nation Convention Against Corruption (UNCAC) and African Union Convention for Preventing and Combating Corruption (AUCPCC) are evaluated (KACC, 20008:11).

\section{Kenya Anti-Corruption Commission's Corruption Prevention Initiatives}

Having identified areas that seem to have rampant cases of corruption, and vested with the institutional mandate to prevent corruption in the country, KACC endeavoured several efforts. These were: Partnerships and Coalitions, Review of Standard Tender Documents, Enhancing Good Governance in Local Authorities Procurement Systems, Management of Records in Public Institutions, Corruption Eradication Indicators for Performance Contracts, Integrity Awards Scheme, Enhancing Governance and Integrity in Private Sector/Professional Associations, Integrity Assurance Officers (IAO) Training Programme, Corruption Prevention Committees (CPC) and Senior Management Training, Follow-Up on Integrity Assurance Officers, Examination and Corruption Prevention Guidelines, Follow-up on the Implementation of Recommendations of the Examination Report on the Registration and Licensing of Motor Vehicles and Enforcement of Traffic Laws and the development of Corruption Prevention Guidelines (KACC,2008). According to KACC Annual Report 2007/2008, the Commission partnered and developed coalition activities mainly in public procurement; management of records in public institutions; development of governance instruments to support performance contracting, formulation of a template for use by public institutions to monitor the corruption eradication indicators under the performance contracts; development of the Public Service Integrity Award Scheme; and enhancing good governance and integrity among private sector/professional associations.

\section{Review of Standard Tender Documents}

The Commission collaborated with the Pubic Procurement and Oversight Authority (PPOA) to review the standard tender documents which provide the framework and the basis for procurement in public institutions. According to KACC (2008), there are 39 prescribed Standard Tender Documents. The exercise addressed loopholes exploited for corrupt practices and devises safeguards to reduce opportunities for corruption; and integrating anti-corruption conditions in the documents. Specific suggestions included Instructions to Bidders: General Conditions of Contract: Selection of Consultants: Selection of Individual Professional Consultants: Procurement of Works: Prequalification Document: Confidential Business Questionnaire Form (CBQ): Anti-Corruption Declaration/ Commitment/ Pledge Form:

\section{Enhancing Good Governance in Local Authorities Procurement Systems}

In its endeavours to prevent corruption, KACC launched Enhancing Good Governance in Local Authorities Procurement Systems. The Commission, the Public Procurement Oversight Authority, and other stakeholders implemented the programme targeting chief officers and members of Tender Committees in Local Authorities. Phase one of the programme exposed participants to the requirements of The Public Procurement and Disposal Act (PPDA) 2005, The 
Public Procurement and Disposal Regulations (PPDR) 2006, and how to address corruption loopholes in the procurement cycle. A practical module guided participants on the design and process of Corruption Risk Assessment (CRA) and consequent formulation of Corruption Prevention Plans (CPP) to address identified risks. 170 chief officers and members of tender committees from Local Authorities from 5 provinces were trained.

\section{Management of Records in Public Institutions}

KACC (2006) observed that proper records are critical in enhancing service delivery and good governance in any institution. To help in streamlining records creation, tracking, control and maintenance in public institutions KACC collaborated with the Kenya National Archives and Documentation Services in the following activities:

\section{Corruption Eradication Indicators for Performance Contracts}

The Commission collaborated with the Office of the Prime Minister-Public Sector Reforms and Performance Contracting to develop measurable components of the "Corruption Eradication" indicators which were incorporated in the Performance Contracts (PC) of all public institutions in 2007/08. The five performance targets for the "Corruption Eradication" indicator were reviewed for incorporation into the performance contracts for 2008/09 for Ministries, StateCorporations, Local Authorities and Tertiary Institutions. Two components were added for implementation in the year 2008/09. A reporting template for use by public institutions to monitor implementation indicators was developed for quarterly and annual reporting.

\section{Integrity Awards Scheme}

The Integrity Award Scheme was launched in 2007, and an adjudication committee comprising representatives from the Cabinet Office, Ministry of State for Public Service, Office of the Prime Minister-Public Sector Reforms and Performance Contracting, the State Corporations Advisory Committee and the Kenya Anti-Corruption Commission was formed. The Scheme sets standards for anti-corruption management systems. It was an opportunity for organizations to review their positions on corruption and identify further actions to minimize corruption risks.

\section{Enhancing Governance and Integrity in Private Sector/Professional Associations}

The Commission, in collaboration with the Association of Professional Societies of East Africa (APSEA) started outreach activities to enhance ethics and good corporate governance among professionals and the private sector as a corruption prevention strategy (KACC, 2007). The Commission continued to undertake the training of Integrity Assurance Officers and Integrity/Corruption Prevention Committees. Other related activities involved follow up in two institutions to determine the efficacy of the programme.

\section{Integrity Assurance Officers (IAO) Training Programme}

KACC trained a total of 488 Integrity Assurance Officers (IAOs) drawn from various sectors in the public service. A followup was conducted in Kenya Ports Authority and Kenya Wildlife Services to identify gaps that required intervention in the IAO training programme and to determine the impact of the IAOs in their organizations. It was observed that some top level managers in these institutions were not committed to the implementation of integrity initiatives. In the two institutions visited the Corruption Prevention Committees (CPCs) were not properly constituted and there was no evidence that any meetings took place. The IAOs trained expressed frustration due to inadequate management support and commitment to their work. Anti corruption policy, codes of conduct and corruption prevention plans were yet to be developed.

This follow-up assisted in mainstreaming anti-corruption strategies in organizations. Training of top managers and Corruption Prevention Committee (CPC) members enhanced appreciation of their obligations for corruption prevention and the need to own and drive the process. According to KACC (2008), many organizations were now setting aside finance and other resources to mainstream integrity through training and development of governance instruments in their respective organizations. These instruments included Corruption Prevention Plans (CPP) which profile corruption prevention initiatives in public organizations and set out levels of responsibility for implementation of the Plans thereby enhancing accountability. 


\section{Corruption Prevention Committees (CPC) and Senior Management Training}

According to KACC (2008), this training targeted senior management and members of the Corruption Prevention Committees. The objective of this training was to equip senior managers and their Committees on process of mainstreaming anti-corruption strategies through the development of appropriate policies and structures and to complement the work of Integrity Assurance Officers.

\section{Examination and Corruption Prevention Guidelines}

As the KACC 2007/2008 Annual Report shows, the Commission, in accordance with its mandate, conducted examination of systems, policies, procedures and practices in the public and private sector agencies. The Commission also provided advisory services to various organizations on various corruption prevention methods. The Commission conducted examination of systems relating to procurement, storage and distribution of drugs and medical supplies; Registration and Licensing of Motor Vehicles and Enforcement of Traffic Laws; Municipal Council of Mombasa; Ministry of Immigration and Registration of Persons - Department of Immigration; the City Council of Nairobi; the Teacher Service Commission; the Roads Sub Sector and the Department of Pensions. Recommendations of these examinations are now being implemented. Key recommendations from KACC (2008) to curb the above loopholes include, among others, development of a national integrated policy on registration of persons, review of The Registration of Persons Act and its Subsidiary Legislation and the introduction of tamper proof birth certificates and identity cards.

\section{KACC'S Education Initiatives to Fight Corruption}

In underscoring education as key avenue in the fight against corruption, KACC developed two main initiatives: Public Education Initiative and Sectoral Integrity Education.

\section{Public Education Initiative}

The Anti-Corruption and Economic Crimes Act 2003 (GK, 2004) empowered KACC to educate members of the public on the dangers of corruption and economic crime and to enlist and foster public support in combating corruption and economic crime. Education is central in inculcating desired knowledge, skills and values that promote national cohesion, development and positive culture. Corruption frustrates efforts to achieve these noble goals. In response, the Commission designs, develops and implements education programmes that cover training on anti-corruption, good governance, ethics and integrity in the public, private and formal spheres (KACC, 2008:63). The Commission has therefore, came with various education programmes that included Media Education Programming, Community Based Anti-Corruption Programme Young Farmers Clubs of Kenya, National and International Days CommemorationsFormal Integrity Education, School Based Anti-corruption Curriculum Support Materials Development, End-Term Evaluation of the Training, Research, Advocacy and Governance (TRAG) Certificate Course, Mainstreaming Anti-Corruption and Integrity Content in Co-curricula Activities, Governance Training for the Ministry of Education Officers and Schools/ Colleges Visits and Opportunity Lectures.

\section{Sectoral Integrity Education}

The Commission engaged in a series of sectoral integrity education, among them, Spiritual Sector Anti-Corruption Education, Law Enforcement Agencies Anti-Corruption/Integrity Education and Curriculum Development, Kenya Institute of Administration (KIA) Trainers Lectures, The Cooperative Sector Integrity and Anti-Corruption Training, Community Based Organization (CBO) Anti-Corruption Project and Public Service Integrity Programme (PSIP). The Commission has accordingly developed several approaches, namely; Spiritual Sector Anti-Corruption Education, Law Enforcement Agencies Anti-Corruption/Integrity Education and Curriculum Development, Kenya Institute of Administration (KIA) Trainers Lectures, The Cooperative Sector Integrity and Anti-Corruption Training, Community Based Organization (CBO) Anti-Corruption Project and Public Service Integrity Programme (PSIP) 


\section{A Critique of the Defunct Kenya Anti-Corruption Commission's Initiatives in the Fight against Corruption}

Before embarking on a discussion with regard to the challenges that face the defunct KACC in its initiatives to combat corruption in Kenya, an exploration of its successes is done.

\section{Successes of the Commission in the Fight against Corruption}

KACC made several initiatives in pursuance of its mandate and functions that resulted in several successes. These are discussed below.

\section{Law Enforcement}

\section{a) Public Involvement and Co-operation}

The Commission gained public enthusiasm in reporting perceived cases of corruption. This made it easier for the Commission to conduct investigations and law enforcement processes as the public come out not only to report, but also to volunteer giving evidence. This hence shows that the Commission continued to gain public cooperation and support in combating corruption. This shows that the Commission succeeded in making the public aware of the dangers of corruption and the need to fight it.

\section{b) Support from other Government Sectors}

Government Ministries, Parastatals and other public institutions co-operated with Commission by incorporating KACC's guidelines to fight corruption. For instance, public institutions established Corruption Prevention Committees, trained Integrity Assurance Officers, raised signs and posters warning against corruption, developed Service Charters and developed rules and regulations to govern against corrupt practices.

c) Parliamentary Support.

The Kenya Parliament passed necessary legislations that empowered KACC to pursue and perform its mandate and functions. Besides, Parliament also enacted other legislations that created institutions that compliment the fight against corruption. This means that KACC's initiatives won the confidence of parliament.

\section{d) Civil Society Support}

The Civil societies, both local and international showed support for KACC's initiatives in the fight against. The civil societies were instrumental in evaluating the performance of the Commission and pointing out its failures as well as areas that needed attention. The civil societies remained instrumental in supporting anti-corruption campaigns.

\section{Investigations and Asset Tracing}

In performing this function, the Commission enjoyed public, parliamentary and international support.

\section{a) Public Support}

The Commission succeeded in having members of the public come out to report perceived cases of corruption. This enabled the Commission to start investigations and or asset tracing.

\section{b) Parliament}

Parliament passed the Witness Protection Act that enables KACC to protect individuals who volunteered information that may be useful while carrying out investigations or tracing assets.

c) International Support 
The United Nations, African Union and other related international organizations developed conventions that call for the independence of KACC. The diplomatic community remained committed to denying visas to those suspected of corrupt practices. Foreign governments started freezing accounts of those suspected of corruption and some were in the process of having extradition agreements with Government of Kenya. This enabled KACC to carry its investigations and asset tracing function.

\section{Public Education}

Through pubic education, KACC created awareness of the effects of corruption, the need to eradicate and report it when suspected cases occur. In this way, the Commission achieved great success.

\section{a) Schools}

Schools joined the fight against corruption through the teaching of moral education as integrated in the syllabus. The schools also incorporated anti-corruption campaigns in co-curricular activities such music and drama. The fusion of anticorruption themes in literature texts is another indicator of the support that the Commission enjoyed from schools.

\section{b) Community Based Organizations}

Members of community based organizations supported KACC's initiative in enhancing awareness about corruption through music and during public functions. This strengthened anti-corruption campaigns, thereby showing that KACC succeeded in winning community support.

\section{c) Mass Media}

Both print and electronic media remained paramount in anti-corruption campaigns. News reporters continued to report on cases of alleged corruption. Further, they carried out anti-corruption messages and advertisements and continued to condemn corruption. The media remained vigilant in reporting corrupt practices. The Commission also succeeded in having the media create awareness of its establishment and mandate and gave coverage its works.

\section{Challenges that KACC Faced in its Anti-Corruption Initiatives}

Several challenges continue to undermine the initiatives of the KACC, despite the successes it made. These challenges could be grouped into two broad categories: legal and operational challenges.

\section{Legal Challenges}

Some of the legal challenges that KACC faced were the definition of corruption by the Act, Poor conception of the meaning of corruption and Limited KACC's Mandate with Regard to Law Enforcement

\section{a) The definition of corruption by the Act}

The Anti-Corruption and Economic Crimes Act, 2003 (the Anti-Corruption Act) defined corruption as an offence with respect to a benefit that is an inducement or reward for, or otherwise on account of, an agent - doing or not doing something in relation to the affairs or business of the agent's principal; or showing or not showing favour or disfavour to anything, including to any person or proposal, in relation to the affairs or business of the agent's principal, bribery, fraud, embezzlement or misappropriation of public funds, abuse of office, breach of trust; or an offence involving dishonesty- in connection with any tax, rate or impost levied under any Act; or under any written law relating to the elections of persons to public office; (The Anti-Corruption and Economic Crimes Act, 2003). The Anti-Corruption Act did not adequately address many of the offences created under UNCAC, e.g. bribery of foreign public officials and officials of public international organizations, illicit enrichment, laundering of the proceeds of crime, trading in influence and obstruction of justice. This way, the Commission did not provide for the holistic criminalization of corruption. 
The Anti-Corruption Act did not have provisions to criminalize corruption in the private sector (Muthomi, 2006). The Act only committed public officers an implication that corruption does not occur in the private sector. This meant that those people who engaged in corrupt activities within the private sector could not be disciplined by KACC. It remained not said how KACC would address a case in which for example a human resource officer in a private sector demanded a bribe or favours to award a tender or employment to undeserving individuals.

The definition of corruption by the Act did not distinguish between corruption and economic crime. The latter was defined as an offence involving dishonesty under any written law providing for the maintenance or protection of the public revenue. It appears from this that not all acts of corruption involve economic crime. Equally, economic crime need not always to involve or amount to corruption, as for the most part, the consequences of corruption and economic crime are identical. These pitfalls in the definition of corruption undermined KACC's initiatives in the enforcement of law as provided in its mandate.

\section{b) Poor conception of the meaning of corruption}

KACC's Annual Reports show that many of the alleged cases of corruption received from the public did not constitute corruption. For example during the period 2003/2004, 3,552 complaints were received. Out of these, KACC instituted investigations on 242 complaints. These were the complaints that fell within the KACC's mandate. The other complaints were handed over to the relevant agencies for further action while no action was taken on 229 complaints.

In the period 2004/2005 (KACC 2004/2005:5), a total of 3,234 complaints of suspected and alleged corruption and economic crime were received at the Commission. Of this number, only $384(11.9 \%)$ were found to merit further investigation by the Commission under its statutory mandate to address corruption and economic crime.KACC 2005/2006 reveals that out of 7,888 reports of alleged corruption and economic crime brought to the Commission's attention by Kenyans, during the reporting year, only $15 \%$ of them fell within the mandate of the Commission, thereby meriting further action by the Commission.

During the year 2006/7 the Commission received 8,188 complaints, reports and other matters from members of the public, public service, and watchdog agencies, as compared to 7,888 in the previous year, reflecting an increase of 300 reports or $3.8 \%$. There was also an overwhelming increase of anonymous reports owing to the introduction of the Webbased anonymous reporting system. Anonymous reports increased by $53 \%$ from 750 in the previous year to 1,151 . Out of the reports received during the year, 1,611 were corruption related and were taken up for investigations. This reflected an increase of cases taken up for investigation from $15 \%$ last year to $20 \%$ during the year 2006/7. The Commission took up 1,611 reports for investigation. Out of these reports, $28 \%$ were handled through preliminary investigation, $26 \%$ special operations, $13 \%$ forensic investigation, and 33\% were taken for intelligence development. During the year, 237 investigations were completed while 115 were referred to external agencies for investigation. In addition, the Commission carried forward 857 cases from the previous years (KACC, 2007:4f.).

These observations point to the fact that the public did not have a clear understanding of corruption. As a result, the few cases that KACC was able to address, versus the reports received could create a sceptical mood among those who report, hence the claim that KACC did not do enough in fighting corruption.

\section{c) Limited KACC's Mandate with Regard to Law Enforcement}

To enable KACC to effectively carry out its law enforcement function, under Section 3 and 4, the Anti-Corruption and Economic Act 2003 provided for the appointment of magistrates to try person who commit offences under this Act. However, the existence and jurisdiction of special magistrates was challenged in court as was made in the High Court of Kenya (Nairobi) Miscellaneous Criminal Application No. 495 of 2003 in which it was stated that the court, had no relationship with the Anti-Corruption Act and therefore it was untenable for the applicant to impugn the Act. It becomes a concern on what the real role of the court was with regard to the mandate of the Kenya Anti-Corruption Commission.

Provisions of Part II of the Anti-Corruption Act related to the procedures and powers of special magistrates in which it was provided that a special magistrate may, with a view to obtaining the evidence of any person supposed to have been directly or indirectly concerned in or privy to an offence, tender a pardon to such person-on condition of his making a full and true disclosure of the whole circumstance within his knowledge relating to the offence and to every other person concerned, whether as principal or abettor, in the commission of the offence. Such pardon, when so tendered, is deemed a pardon for purposes of section 77(6) of the by then Constitution of Kenya. It emerges here that the Commission could not have effectively carried out its mandate given this seeming discrepancy. 
Section 5 of the Anti-Corruption Act accorded with the provisions of Article 37 of UNCAC, which obliges State Parties to take appropriate measures to encourage persons who participate in or who have participated in the commission of an offence established under the Convention to supply information useful to competent authorities for investigative and evidentiary purposes and to provide factual, specific help to competent authorities that may contribute to depriving offenders of the proceeds of crime and to recovering such proceeds. Section 5 of the Act provided that a special Magistrate may, with a view to obtaining the evidence of any person supposed to have been directly or indirectly concerned in, or privy to, an offence, tender a pardon to such person on condition of his making a full and true disclosure of the whole circumstance within his knowledge relating to the offence and to every other person concerned, whether as principal or abettor, in the commission thereof and any pardon so tendered shall be a pardon for purposes of section 77(6) of the Constitution ( The Anti-Corruption and Economic Crimes Act, 2003: 8)

According to the by then Kenya Constitution, Protection of Fundamental Rights and Freedoms of the Individual was contained in Chapter Five and had sixteen sections that ranged from section 70 to section 86 . Section 77 had provisions to secure protection of law. It was a section which provided that every person who was charged with a criminal offence shall be presumed to be innocent until proved or pleaded guilty (Kenya, Republic of, 1992). Section 77(6) stated that no person shall be tried for a criminal offence if he shows 'that he has been pardoned for that offence (Kenya, Republic of, 1992).

In particular, the pardon provided by section 5 of the Anti-Corruption Act accorded with the requirement for State Parties to consider the possibility of granting immunity from prosecution to a person who provides substantial cooperation in the investigation or prosecution of an offence established in accordance with the provisions of the Convention. It states that each State Party shall take appropriate measures to encourage persons who participate or who have participated in the commission of an offence established in accordance with this Convention to supply information useful to competent authorities for investigative and evidentiary purposes and to provide factual, specific help to competent authorities that may contribute to depriving offenders of the proceeds of crime and to recovering such proceeds consider providing for the possibility, in appropriate cases, of mitigating punishment of an accused person who provides substantial cooperation in the investigation or prosecution of an offence consider providing for the possibility, in accordance with fundamental principles of its domestic law, of granting immunity from prosecution to a person who provides substantial cooperation in the investigation or prosecution of an offence established in accordance with this Convention.(UN, 2004: 27). This seeming conflict of the legal provisions raises questions on the efficacy of the Commission when it carried out investigations and collection of evidence.

\section{Operational Challenges}

\section{a) Operational Parameters}

The Anti-Corruption and Economic Crimes Act, 2003 lacked many of the significant features and obligations imposed on State Parties under UNCAC. It did not, for instance, make sufficient provision for international cooperation and technical assistance in the prevention of and fight against corruption, yet Kenya is a signatory to UNCAC. Section 12(2) of the AntiCorruption Act states that the Commission may in the performance of its functions work in co-operation with any foreign government or international regional organization (The Anti-Corruption and Economic Crimes Act, 2003). This provision by the Act was only a minimal provision on international co-operation, the Act did not provide for the mode and scope of international cooperation. Further, since the Act did not address trans-boundary aspects of corruption, it can legitimately be argued that the cooperation envisioned under the Act only related to matters touching on corruption or economic crimes committed in Kenya. In fact, section 67 of the Act which stated that conduct by a citizen of Kenya that takes place outside Kenya constitutes an offence under this Act if the conduct would constitute an offence under this Act if it took place in Kenya(The Anti-Corruption and Economic Crimes Act, 2003).

The implication of the above observation is that the Act only criminalized extra-territorial offences committed by Kenyan citizens. In the absence of a local law domesticating the provisions of UNCAC, it is legitimate to argue that Kenya had no legal sanctions against transnational aspects of corruption. Consequently, KACC had no mandate on the offences being committed under these circumstances. It is therefore evident that KACC and its initiatives were limited to the people of Kenya. 


\section{b) Co-ordination and Harmonization}

The fact that the Anti-Corruption Act limited KACC to investigations without prosecutorial powers was a major shortcoming of the Act. It is noted that KACC "lacked the teeth" to bite corrupt officials. This was because the Attorney General could decide not to prosecute individuals even after investigations by KACC.

It is arguable that the establishment of KACC under the Anti-Corruption Act did not fully meet Kenya's obligations under Articles 5 and 6 of UNCAC. Article 5 of UNCAC obliges State Parties to develop and implement or maintain effective, coordinated anti-corruption policies that promote the participation of society and reflect the rule of law, proper management of public affairs and public property, integrity, transparency and accountability. Article 5 of UNCAC states that Each State Party shall, in accordance with the fundamental principles of its legal system, develop and implement or maintain effective, coordinated anti-corruption policies that promote the participation of society and reflect the principles of the rule of law, proper management of public affairs and public property, integrity, transparency and accountability to establish and promote effective practices aimed at the prevention of corruption endeavour to periodically evaluate relevant legal instruments and administrative measures with a view to determining their adequacy to prevent and fight corruption as appropriate and in accordance with the fundamental principles of their legal system, collaborate with each other and with relevant international and regional organizations in promoting and developing the measures referred to in this article. That collaboration may include participation in international programmes and projects aimed at the prevention of corruption (UN, 2004:9).

It appears that there was no coordination in implementing anti-corruption measures and policies. Though section 12 of the Anti-Corruption Act provided for cooperation between KACC and other bodies, for instance, it was witnessed conflicts between KACC and the office of the Attorney General. Though section 12 obliged public bodies and officers to cooperate with KACC, it should be contrasted with multiple constitutional and statutory provisions which provided that certain officers and bodies were not subject to the control and direction of any person or authority. KACC's success seemed to be dictated by the Attorney General's office as it decided on which cases to be prosecuted.

Still on coordination and harmonization of anti-corruption measures and policies, it is not clear whether officers of the Anti-Corruption Unit of the Kenya Police Force were answerable to the by then Commissioner of Police or Director of KACC. In short, the provisions of section 12 of the Anti-Corruption Act fall below the requirement set out in Article 38 of UNCAC. Under Article 38, each State Party is obliged to take such measures as may be necessary to encourage cooperation between its public officials and authorities on the one hand and its authorities responsible for investigating and prosecuting criminal offences under the Convention. There are no known measures in Kenya, legal, policy or administrative, obliging public authorities and officials to assist and cooperate with KACC.

\section{c) Challenges facing the Investigations Initiative}

The Commission faced several criticism over the manner in which it executed its mandate as provided by the Act. In fact the Commission admitted this in its 2006/2007 Annual Report. The Commission stated that weaknesses in the anticorruption legislation, including the lack of transparency in wealth declarations, lack of a mechanism of investigating breaches of codes of conduct and ethics by public officers undermined its work (KACC, 2007: 5). The Commission pointed out that the recovery of looted public property was not possible because of The Limitation of Actions Act (Cap. 22). According to this Act, the time limits for actions based on breach of contract, breach of trust and unjust enrichment was six years, while for actions based on tort such as theft or fraud it was three years. This meant that most of the misappropriated public funds could not be recovered unless the Act was amended to remove these limits.

\section{d) Lack of Anti-Corruption Education Programmes}

The initiative by KACC towards anti-corruption education met the requirements of Article 6(1) (b) of UNCAC, which obliges State Parties to ensure the existence of a body or bodies to increase and disseminate knowledge about the prevention of corruption as part of preventive measures. Article 6(1) (b) of UNCAC provides that each State Party shall, in accordance with the fundamental principles of its legal system, ensure the existence of a body or bodies, as appropriate that prevent corruption by such means as increasing and disseminating knowledge about the prevention of corruption (UN, 2004:10). However it is noted that KACC lacked a clear curriculum, trained teachers and teaching methodology. Though the Commission tried to examine learners on the knowledge of anti-corruption education, it is regretted that such evaluation attempt was not defined nor articulated. 
The Commission did not articulate the goals of its public education initiatives and neither did it necessarily draw the objectives. Consequently, this undermined the drawing of curriculum content. It further undermined the logical structure of such content to meet the learning needs and levels of consumers (learners).

The use of co-curricular presents another challenge in that whereas corruption causes such devastating effects on mankind, the use of forums such music and drama paints a picture of people celebrating in their own jubilation. On many occasions one would see students dancing and celebrating that they have won the trophy and the accompanying joy of victory. Furthermore, composers may be making efforts in their work, not because they want to spread the message of anti-corruption, but to win the trophy and the fame that comes with such victory.

The absence pedagogical provisions, KACC's educational initiatives did not have lesson plans. Lessons were not planned or were they schemed. Ideally, what seems to have happened is that these public educational programmes were playing entertainment role rather educational. For example, when a school presented a dramatized dance it is not clear whether the audience came for the message on corruption or came for love of drama and therefore entrainment. The same thing applies to music. Furthermore, a team that scores a highest mark in drama or music does not really imply that the team convinced many people to change their corruptive behaviour. It is because the team applied the rules of drama or music correctly, as the final score is based on such aspects.

Raising of consciousness about the norms and ethics of the profession may contribute to increasing job satisfaction among teachers and education personnel, to enhancing their status and self-esteem, and to increasing respect for the profession in society Education personnel shall: a) justify public trust and confidence and enhance the esteem in which the profession is held by providing quality education for all students; b) ensure that professional knowledge is regularly updated and improved; c) determine the nature, format and timing of their lifelong learning programs as an essential expression of their professionalism; d) declare all relevant information related to competency and qualifications; e) strive, through active participation in their union, to achieve conditions of work that attract highly qualified persons to the profession; f) support all efforts to promote democracy and human rights in and through education (El Declaration on Professional Ethics, Section 9). Besides the failure to provide for the professional qualification of those involved in the practice of public education, KACC did not provide for the ethical conduct as contained in the declaration.

\section{Conclusion}

In seeing corruption as amoebic in nature (that is, without a definite form), this paper has shown that it occurs in various forms and a wide range of places such that there seems to be no single approach to its eradication. Using reflections from the defunct Kenya Anti-corruption Commission, it has been further shown that corrupt individuals exploit existing gaps in legislation to evade justice, a condition created by the very fluid nature of corruption in which it rests on varying interpretation. This way, this paper concludes that anti-corruption initiatives should be conceived in a dynamic manner that could be applicable in times when corruption changes faces. From the discussion in this paper, it is further concluded that:

a) Corruption has devastating effects of human beings. Corruption is increasingly seen as a serious crime with devastating consequences such as wasteful spending, bigger budgetary deficits, great economic inequalities, disinvestments as well as unorthodox trading practices. It continues to undermine good governance and to distort public policy, leading to misallocation of resources.

b) The devastating effects of corruption are the driving forces in anti-corruption initiatives.

c) With regard to the fight against corruption, education is central in inculcating desired knowledge, skills and values and its use in combating corruption should focus on the will to know how to act.

\section{References}

Ades, A, and DiTella R. (1997). "Rents, Competition and Corruption," American Economic Review. New York. , 1997, "National Champions and Corruption: Some Unpleasant Interventionist Arithmetic," Economic Journal, Vol. 107 (July).

African Union (2003). African Union Convention on Preventing and CombatingCorruption (AUCPCC). The 2nd Ordinary Session of the Assembly of the Union in Maputo, Mozambique on 11 July 2003.

American Convention against Corruption (1996): Framework for Combating Corruption. Washington. World Bank.

Annan K. (2006): Preface. In: The UN Anti-corruption Tool Kit (2004). United Nations. New York.

Anechiarico, Frank and James B. Jacobs (1998). The Pursuit of Absolute Integrity: HowCorruption Control Makes Government Ineffective. Chicago: University of Chicago Press, 1998. 
Bardhan, P, (1997). "Corruption and Development: A Review of Issues," Journal of Economic Literature, Vol. 35 (September).

Becker, Gary S., 1968, "Crime and Punishment: An Economic Approach," Journal of Political Economy, Vol. 76 (March/April).

Becker, Gary S., and George J. Stigler, 1974, "Law Enforcement, Malfeasance, and Compensation for Employees," Journal of Legal Studies (January).

Bellow, Adam,(2003). In Praise of Nepotism. New York: Doubleday.

Braguinsky, Serguey, 1996, "Corruption and Schumpeterian Growth in Different Economic Environments," Contemporary Economic Policy, Vol. 14 (July).

Brunetti, Aymo, and Beatrice Weder, (1998), "A Free Press Is Bad News for Corruption,"WWZ Discussion Paper No. 9809.

Christopher Mulei, "Corruption in the Court System", in Andrew Mullei (Ed) The Link Between Corruption and Poverty: Lessons from Kenya, African Centre for Economic Growth, Nairobi, 2000, p.123.

Crank, J, Caldero, M. (2004). Police Ethics: The Corruption of Noble Cause. Cincinnati: Anderson Publishing.

Ferrero, M, and Giorgio B. (1997). "Nomenklatura Rule Under Democracy: Solving the Italian Political Puzzle," Journal of Theoretical Politics, Vol. 9 (October).

Heidenheimer, A, J. and Michael J. (eds.) (2002). Political Corruption: Concepts and Contexts, $3^{\text {rd }}$ ed. London: Transaction Publishers.

High Court of Kenya (2003). (Nairobi) Miscellaneous Criminal Application No. 495 of 2003. Nairobi.

Hindes, K (2001). Political Corruption in the United States.New York. Transaction Publishers.

Hopkins, J. (2002) "States, Markets and Corruption: A Review of some Recent Literature" Review of International Political Economy 9(3).

Johnston, M, (1997), "Public Officials, Private Interests, and Sustainable Democracy: When Politics and Corruption Meet," in Corruption and the Global Economy, ed. by Kimberly Ann Elliott (Washington: Institute for International Economics).

KACC (2004): Kenya Anti-corruption Commission Annual Report 2003/2004. Nairobi.

KACC (2005): Kenya Anti-corruption Commission Annual Report 2004/2005. Nairobi.

KACC (2006): Kenya Anti-corruption Commission Annual Report 2005/2006. Nairobi.

KACC (2007): Kenya Anti-corruption Commission Annual Report 2006/2007. Nairobi.

KACC (2008): Kenya Anti-corruption Commission Annual Report 2007/2008. Nairobi.

Kanyinga, K. (2004). "New Anti-Corruption Governments: the Challenges of Delivery: A Case Study of Kenya." Paper commissioned for the Kenya Meeting on New Governments, co-organised by the Government of Kenya, TI-Kenya and Transparency International, held in Nairobi, Kenya, in October 2004.

Kaufmann, D. (1997). "The Missing Pillar of a Growth Strategy for Ukraine: Reforms for Private Sector Development," in Ukraine: Accelerating the Transition to Market, ed. by Peter Cornelius and Patrick Lenain (Washington: International Monetary Fund).

_ (winter).

Kenya, Republic of (1992). The Constitution of Kenya, Chapter V, Protection of Fundamental Rights and Freedoms of the Individual Section 77: Provisions to Secure Protection of Law Revised Edition (1998) 1992. Nairobi. Government Printer.

Kenya, Republic of (2003). The Anti-Corruption and Economic Crimes Act, 2 Nairobi. Government Printer.

Kibwana, K. Kichamu, S. (2001).. Initiatives against Corruption in Kenya Legal and policy Interventions, 1995 - 2001. Nairobi. Clairpress.

Kimberly A. E., (1997). Corruption and the Global Economy. New York. John Wiley and Sons.

Kivutha K, Smokin W, Oketch-Owiti (2005). The Anatomy of Corruption in Kenya: Legal, Political and Socio-Economic Perspectives (Review), Nairobi, a case study of the Goldenberg Export Compensation payments.

Klitgaard, R, (1991). Controlling Corruption. Berkeley: University of California Press.

Klitgaard, Robert, Ronald M, and Lindsey P. (2000). Corrupt Cities: A Practical Guide to Cure and Prevention. Oakland, CA: ICS Press.

Klitgaard, R. E. (1988), Controlling Corruption (Berkeley, California: University of California Press).

Kopits, G, and Jon Cr, (1998), "Transparency in Government Operations," IMF Occasional Paper No. 158 (Washington: International Monetary Fund).

Kpundeh, G. (2006). Legal Frameworks and the Roots of World's Corruptive Affairs. New York. New York Press Ltd.

Kpundeh, S. (1999). Corruption: Integrity Improvement Initiatives in Developing Countries. UNDP 1999 as quoted by Camerer, in Terms of Endearment: Bilateral Donor Engagement in Fighting Corruption in South Africa, Anti-corruption Strategies Project, Institute for Security Studies, Cape Town Volume 9 Number 5/6/2000.

Lindbeck, A. (1998). "Swedish Lessons for Post-Socialist Countries" (unpublished; Stockholm: University of Stockholm Institute for International Economic Studies).

Mbula, K. (2008). How Kenyans Understand Corruption: The Case of Knowledge versus Hearsay. Unpublished Seminar Paper, Presented at the World Conference on the Challenges of Achieving Millennium Development Goals, The Hague.

Michael J. (2005). Syndromes of Corruption: Wealth, Power, and Democracy. London. OxfordUniversity Press.

Miller, Seumas, 2005. Peter Roberts, and Edward Spence, Corruption and Anti-Corruption: An Applied Philosophical Approach. New Jersey: Prentice Hall, 2005.

Murphy, K, M. Andrei S, and Robert W. V. (1991). "The Allocation of Talent: Implication for Growth," Quarterly Journal of Economics, Vol. 106 (May).

Monica, A. (2004) "Networking Civil Society in Latin America", in Supra fn.

Muite, P. (2007). No More Powers for KACC. Daily Nation 14th June 2007. 
Namwamba, A. (2005). Politics and Corruption: Understanding the Kenya's New Constitution draft. Daily Nation. $23^{\text {rd }}$ October 2005.

Muthomi T. (2006) The Anti-Corruption and Economic Crimes Act, 2003; Has Kenya Discharged her Obligations to Her Peoples and the World?. Unpublished

Ngugi, A . (2007). Message from the Chairman. In:Kenya Anti-corruption Commission Annual Report 2006/2007. Nairobi.

Njui, A. (n.d) Director, Catholic Justice and Peace Commission (CJPC) in an undated paper: "The Role of Religious Institutions and Civil Society in Elections".

Procter, A. (1980). Longman s Dictionary of Contemporary. London. Longman.

Rauch, J. E., and Peter B, (1997). "Bureaucratic Structure and Bureaucratic Performance in Less Developed Countries" (unpublished: San Diego, California and Berkeley, California; University of California at San Diego and University of California at Berkeley).

Ringera (2007). "Message From the Director." In: Kenya Anti-corruption Commission Annual Report 2006/2007. Nairobi.

Ruhiu, M (n.d) Corruption: A moral Disease. Nairobi. Lectern.

Rose-Ackerman, S., (1997). "Corruption and Development," paper prepared for the Annual Bank Conference on Development Economies, Washington, D.C., April 30 and May 1.

Rose-Ackerman, S. (1999). Corruption and Government: Causes, Consequences and Reform. Cambridge: CambridgeUniversity Press.

Shleifer, A. (1996). "Government in Transition," HIER Discussion Paper No. 1783 (Boston, Massachusetts: Harvard Institute for Economic Research). , and Vishny R.W. (1993). "Corruption," Quarterly Journal of Economics, Vol. 108 (August).

Simis, C. M. (1982). USSR: The Corrupt Society. The Secret World of Soviet Communism (New York: Simon and Schuster).

Tanzi, Vito, (1995a). "Corruption, Arm's-Length Relationships, and Markets," in The Economics of Organised Crime, ed. by Gianluca Fiorentini and Sam Peltzman (Cambridge, Massachusetts: Cambridge University Press), pp. 161-180.

(1995b). "Government Role and the Efficiency of Policy Instruments," IMF Working Paper 95/100 (Washington: International Monetary Fund). Also published in Public Finance in a Changing World, ed. by Peter Birch Sørensen (New York: Macmillan), pp.

(1998). "Corruption and the Budget: Problems and Solutions," in Economics of Corruption, ed. by Arvind K. Jain (Boston, Massachusetts: Kluwer Academic Publishers).

_ International Monetary Fund).

Tanzi, V, and Ludge, s. (1997). "Reconsidering the Fiscal Role of Government: The International Perspective," American Economic Review, Papers and Proceedings, Vol. 87 (May).

Theobald, R. (1990). Corruption, Development, and Underdevelopment (Durham, North Carolina: Duke University Press).

The Fourth World Congress of Education International (El):Resolution on the Role of Education in Combating Mismanagement and Corruption Meetingheld in Porto Alegre, Brazil, from 22 to 26 July 2004:

Third World Congress of Education International: El Declaration on Professional Ethics. Meeting in Jomtien, Thailand, from 25 to 29 July, 2001.

Transparency International (2008): anti-corruption education/education/other thematicissues/globalww.transparency.org/ global_priorities/other_thematic_issues/education/anti-corruption_education - 21k.

Transparency International (TI, 2007): 2007 Corruption Survey Index. Berlin. TI

Transparency International (TI: 2006):2006 Corruption Survey Index. Berlin. TI

United Nations. (2001). UNCAC .UN. New York (2003). Manual on Anti-corruption Policy. (2003). UN. New York (2004). The UN Anti-corruption Tool Kit (2004). UN. New York. (2006). Anti-corruption Policy. UN. New York

Report of the World Summit for Social Development in Copenhagen, 1995 p. 4.Specifically, programmes should target young people, putting emphasis on moral ethics. The Quarterly Newsletter of Transparency International (Kenya) on Fighting Corruption in East Africa, Issue One April 2001 in Daily Nation May 1.

Van Tulden, F, and van der Torre, A. ( 1997). "Crime and the Criminal Justice System: An Economic Approach," paper presented at the $53^{\text {rd }}$ Congress of the International Institute of Public Finance, Kyoto, Japan, August.

Van Rijckeghem, C, and Weder, B. (1997). "Corruption and the Rate of Temptation: Do Low Wages in the Civil Service Cause Corruption?" IMF Working Paper 97/73 (Washington: International Monetary Fund).

Weber, M. (1947). The Theory of Social and Economic Organization (London: The Free Press of Glencoe).

World Bank (1997). Helping Countries Combat Corruption: The Role of the World Bank. Washington DC: World Bank. 